\title{
1. The question of inequalities during the Progressive Era in the United States: the "Golden Mean" program of the economist Richard T. Ely
}

Michel Rocca

\section{INTRODUCTION}

"Markets can also concentrate wealth, pass environmental costs on to society and abuse workers and consumers. For all these reasons, it is plain that markets must be tamed and tempered to make sure they work to the benefit of most citizens. And that has to be done repeatedly, to ensure that they continue to do so. That happened in the United States in the "Progressive Era", when competition laws were passed for the first time. [. . .] Markets, by themselves, even when they are stable, often lead to high levels of inequality, outcomes that are widely viewed as unfair" (Stiglitz 2012: xlii). In 2012 Joseph Stiglitz carried out a diagnostic of the state of society already assessed in the same terms by the economist Richard T. Ely as far back as 1884 during "the age of the robber barons" (Ely 1884). This diagnostic was to be Ely's first step toward formulating a "Golden Mean" program with a view to reforming an American Society of the Gilded (1865-1901), deemed to be intrinsically unequal.

A leading "light" of the Progressive Era in the United States (1880s-1930s), Richard T. Ely (1854-1943) was an eminent American late nineteenth-century academic (Coats 1993). ${ }^{1}$ Ely is viewed as a major organizer and forerunner of the profession of economist, especially by institutional economists. Furthermore, Ely advocated social reform and intellectual alternatives borrowed from the German Historical School (GHS) teachings (Gough 1991; Rutherford 2009).

Richard T. Ely promoted a project inspired by his education (from 1877 to 1880, Ely studied in Halle, Heidelberg and Berlin before obtaining academic positions in the United States), and more particularly by his life as a young intellectual seduced by the Europe of the 1870s. While this project displayed an ambition to build a progressive, stable and harmonious society, it also 
explicitly aimed to avoid confrontation between the classes leading to revolutions affecting the order of society (Ely 1918: 124). This fear of revolution would be the driving force behind the project of a very religious, philosophically conservative man of aristocratic stock.

Ely marked the Progressive Era by the political and intellectual magnitude of the project he proposed in four main works, ${ }^{2}$ as well as a vast canon of publications, monographs and articles. ${ }^{3}$

The "Golden Mean" project comprised three main components developed progressively over a lifetime dedicated to economic research and militant action in favor of societal reform. The first component was a radical criticism of the unequal order resulting from the industrial society of the late nineteenth century (Section 2). Using the methods of the GHS, as well as empirical approaches, Ely's criticism, addressing the unequal society of the United States, was actually an analysis of poverty related to the conditions of workers. The analysis of the end of the Pullman strike in 1894 was the culmination of Ely's criticism. The second component formulated a theoretical proposal designed to enable American capitalism to avoid conflict between the classes by envisaging the introduction of a new "bundle of rights," particularly in relation to private property (Section 3). The principles of a new socio-economic order promoting the general interest rather than the privileges of just a few were explained in his work of 1914, which allocated to the state a normative role in economic life, thereby redefining the rights of access to wealth. The third component put forward a relatively precise template for action in order to implement the institutional reforms necessary for this new conception of rights (Section 4).

In conclusion, we will demonstrate that, while Ely's project did indeed have an impact on American society, it was only much later that the second New Deal took effect (Section 5).

\section{ELY AND THE CRITICISM OF CAPITALISM: A HOTBED OF INEQUALITIES . . . JUSTIFIED BY THE "OLD POLITICAL ECONOMY"}

Ely's works were developed during singular, ambivalent periods in the United States: the Gilded Age and the Progressive Era. These periods experienced both a rapid growth of the main economic activities (railroads, factories, banks, mines, etc.) and the first major crises in the American capitalist system. Rapidly increasing wealth among major entrepreneurs benefiting from industrial concentration was contrasted by growing inequalities and the rise of severe poverty. Over the period 1883-85, Ely's academic works were unprecedentedly guided by this characterization of an unequal society, explaining it through the application of an unfounded economic doctrine that 
was self-satisfying, even justifying the status quo. The work "The Past and the Present of Political Economy" (1884) took up the essence of these writings to serve up Ely's first overall reflection, published as a book.

During his most productive period (1884-1914), Ely's works presented a methodical criticism of capitalism. From the outset, he leveled criticism at both the order of society and the economic thought underpinning it. These somewhat abrasive articles were nevertheless acknowledged for their qualities and their considerable originality (Dorfman 1949). ${ }^{4}$

A first criticism therefore analyzed the unequal mechanisms of the capitalism of the Gilded Age. Ely believed that this capitalism displayed the particularity of amplifying "more natural human inequalities" (greater intelligence, gifts, ability, talents) (Bradizza 2013: 30-31). As an intellectual and Christian militant, Ely examined these inequalities constructed by the American Society of the Gilded Age through the prism of increasing poverty. Faithful to the methods of the GHS, Ely studied this poverty in great detail in several monographic and highly empirical texts. A summary text entitled "Pauperism in The United-States" was published in 1891.

Through an approach not previously adopted by other economists, this explanation of the unequal mechanisms of capitalism targeted the exercise of capital ownership rights in the USA, which prevented the fair distribution of wealth created by production.

The second criticism demonstrated that this increase in inequalities resulted from the adoption of an economic policy that was inappropriate, as the latter was based on the ideas of the "Old Political Economy" or, in other words, classical English economics (Kloppenberg 1986: 208). According to Ely, "[the old political economy] doctrines purporting to disclose natural laws harmonizing private and public interests and to support a laissez-faire policy allow the greedy and avaricious to use them as a tool for keeping down and oppressing the labor class" (Ely 1884: 64).

Ely believed that classical economic theory posed a whole host of problems, which were presented in his 1889 book, An Introduction to Political Economy. He identified three levels of problems. Philosophically speaking, the conception of the classical theory prevented both ethical concerns and the very idea of change from being considered (Frey 2008). Emblematic of the status quo, of a "theological determinism" and ultimately of a form of "absolutism" (Rader 1966), this theory was impermeable to the problems of society, and in particular of the most deprived, whom Ely felt should be the prime concern. Finally, through a strictly deductive axiom aimed at identifying the laws of economics, this theory produced solutions incorrectly deemed valid at all times and in all circumstances. The criticism of a belief that the market is the optimum form of resource allocation was already present. 
This explains Ely's decision to examine the social sciences from a moral standpoint in order to demonstrate how society works and to endeavor to improve it (Ely 1886b). There is a direct link to the ideas of Gustav von Schmoller, a pioneer of the "historical method" of the second GHS during the 1870s. ${ }^{5}$ Furthermore, by studying the social experimentation observed in Pullman in 1885, Ely showed that other solutions, while difficult, were possible in order to develop more harmonious social rules in American capitalist society (Ely 1885).

\section{ELY AND THE "SOCIAL THEORY OF RIGHTS": BUILDING A FAIRER SOCIETY}

Ely's criticism called directly for the transformation of capitalism, rejecting the laissez-faire approach. This rejection led to a new means to promote the development of economic discipline (Rocca and Vallet 2019). In particular, Ely believed that it was essential to make space for the effective analysis of human choices in economic life and to develop the precise methods of investigation to facilitate this (Ely 1889). In our view, E. W. Morehouse's work (1969) provides the most faithful summary of this desire for renewal, the aim of which was to understand economic and social phenomena rather than hunting for improbable laws that governed them.

Incidentally, these new theoretical perspectives were accompanied by a number of somewhat ironic utterings that the history of thought has retained as being revealing of institutional intuition, ${ }^{6}$ as well as by the formulation of theoretical outlines for economic research: a more inductive form of research (not just counter-factual), more concerned with collecting facts (not just identifying the supposed laws of economics) and with proposing solutions for reform (rather than simply serving a liberal approach to economic phenomena). However, this criticism of classical economics was not the culmination of Ely's approach, even if the history of thought sees it as a founding element of the institutional school: such a criticism was rather the means of transformation capitalism.

Calling on his analysis of institutions (and not merely the price-setting on the market), Ely clearly laid out his project in his major work published in 1914. In Property and Contracts in Their Relations to the Distribution of Wealth (995 pages in two volumes), Ely extended his criticism of laissez-faire policy and classical theory to an analysis of property rights as a factor preventing change. He believed that these property rights should be altered through robust state action (Ely 1914).

In Socialism and Social Reform (1894), Ely's choice already appeared clear: he rejected the idea - hotly debated at the time - of taxing the income (of the rich) to finance the redistribution of wealth, favoring institutional change 
instead. The latter was supposed to establish a fairer and globally more efficient wage-profit-sharing than the simple distribution of incomes (Bradizza 2013: 87). As a progressive conservative, and despite the marked inequalities observed in the USA at the end of the nineteenth century, Ely made a clear choice: to prioritize the path of resources obtained through work over income (of the poorest) obtained through redistribution made possible by taxing incomes (of the wealthiest).

In Property and Contracts in Their Relations to the Distribution of Wealth, Ely confirmed this path toward reform, becoming the pre-institutional theoretician who very directly inspired his student, John R. Commons. Indeed, this work marked a fundamental milestone in the development of institutional thought, explicitly connecting an investigative methodology, a theory of property rights and an application to the theoretical problem of the distribution of wealth (Obeng-Odoom 2015: 889). According to Rutherford (2001: 176-7), Ely earned a specific place in the laying of the foundations of institutional tradition with his 1914 work: "Except for material on intangible property, little of this emphasis on law and economics came directly from Veblen. The major sources were the legal-economic work of Richard Ely (who taught Commons) and H. C. Sumner (who taught Hamilton). They, in turn, had been very much impacted by their exposure to the German Historical School."

Property and Contracts in Their Relations to the Distribution of Wealth also sparked the most virulent criticism of Ely from liberal economists: taking up the accusations voiced by Simon Newcomb of Johns Hopkins University in 1884 , this attack returned to his supposed socialist leanings ${ }^{7}$ and the need to remove him from the university.

This major work developed three ideas in particular:

1. The long-term accumulation of capital was fundamentally unstable as a result of the existence of the distribution of hereditary property rights. As Kummerow notes (2004: 2), "rather than 'trickling down', property rights 'pump up' wealth and income, tending to increase [the] concentration of wealth and political power over time." This could foster investment in the short or medium term but could tend to weaken demand in the long run because the average propensity to consume falls with income. Therefore, if hereditary property rights give a larger percentage of national income to the wealthy, less consumption and more saving would be the outcome. Ely believed that this economic system generated poverty that could not be reduced, assuming forms similar to the conditions of slavery (Ely 1914: 806).

2. This situation of poverty and growing economic inequalities could only improve if the fundamental rights were to change in society. In Ely's opinion, an institutional reform of property rights was the only means of achieving a fair and efficient economy. In tangible terms, it was impossible 
to continue believing that capitalism was synonymous with total freedom of action of the owner - a total freedom that the Constitution was supposed to guarantee and the judges were to supervise.

Based on numerous appendices to the chapters of Property and Contracts in Their Relations to the Distribution of Wealth, Ely analyzed judgments and characterized the influence of a property right (over capital) that the courts of justice deemed absolute and inalienable. Globally speaking, Ely had a different theoretical conception of the role of law in economic functioning, seeing law as promoting social well-being.

Ely defended a change in the principle of constitutionally inalienable property rights, as the following quotation summarizes:

Property has its social side, as represented by the right of taxation, the right of eminent domain, the right to exercise the police power, the right to control transfers, especially by way of inheritance, the right to exempt certain property from execution and distress in order that a man may not be deprived of the means of doing his part in the work of the world by working at his trade or calling. An absolute right of property, free from these restrictions for the benefit of organized society, would [. . .] result in the dissolution of society. It is these considerations that sustain one of the main theses of the book, that private property is established and maintained for social purposes. (Swayze 1915: 825)

The trend favored by Ely was an increased incorporation of what he termed "public interest" (now referred to as general interest) in exercising private property rights (and not its abolition).

3. The necessary change in property rights was possible without contracting the Constitution (this was incidentally the case for the abolition of slavery). According to Ely, the rights specifically linked to the distribution of wealth should be progressively reformed. In practice, reforms were not intended to abolish property rights but rather to impose an allocation of wealth created in a more socially fair manner. Different institutions would have to be modified:

In the existing socio-economic order, there are five fundamental institutions of first rank: (1) property, public and private; (2) inheritance; (3) contract and its conditions; (4) vested rights; and (5) personal conditions. In addition, there are five fundamental forces of second rank: (1) custom; (2) competition; (3) monopoly; (4) authority; and (5) benevolence. It is these fundamental institutions and forces that radical socio-economic reformers desire to change. It must be admitted. (Swayze 1915: 822)

A change in the "bundle of rights" should thus be designed to achieve new balances between the individual freedoms to be protected at all costs (capital ownership right) and social institutions that restrict owners while 
also guaranteeing the individual freedom of worker-citizens. From 1914 Ely advocated not only the introduction of new tools to steer the economy, but more particularly a set of constraints designed to achieve these new equilibria. The constraints were either new institutions (the creation of unions, for example) or new rules (legal provisions with regard to wages, sharing the wealth created and child labor).

This project of Ely's was not isolated..$^{8}$ It was even relayed and amplified by many of the students who became professors or leading politicians during the Progressive Era. Summarizing the literature on this point, Kummerow (2004:

7) lists the variety and strength of the relays from which Ely's ideas benefited:

- Wesley Mitchell contributed to improving information by helping to create institutions to produce national accounts data.

- John R. Commons lobbied effectively for the legalization of labor unions.

- Thorstein Veblen attacked the assumption of rationality, developing the idea that people act through "habits" to achieve status in social contexts, rather than as individually autonomous decision-makers.

- Woodrow Wilson (Ely 1900), who minored in Economics under Ely at Johns Hopkins, became a reformist president whose administration passed child labor laws and pure food and drug laws.

- Frederick Jackson Turner wrote a key essay on the closing of the American frontier and hence the need to conserve natural resources.

- Theodore Roosevelt did not study under Ely, but read his works, commenting that "Professor Ely taught me to be radical in my economics and then sane in my radicalism" (Ely 1938: 248). Roosevelt especially paid attention to Ely's 1900 work on monopoly and was known as a "trust buster." Roosevelt also set aside public land for conservation purposes.

- Many other Ely students developed institutions for land-use regulation, property taxation and real-estate valuation.

While the "Golden Mean" was theoretically sound and very clear in its aims, it also displayed the originality of containing the definition of its means of implementation.

\section{ELY, A PALADIN ${ }^{9}$ COMMITTED TO THE REFORM OF SOCIETY'S INSTITUTIONS}

On a personal note, Ely had a conception of the role of the state that was influenced by his faith. In contrast to the Darwinian approach to society dominant in the USA at the time, he relied on a redemptive conception of the role of the state: "In Ely's eyes, government was the God-given instrument through which we had to work. Its preeminence as a divine instrument was based on the 
post-Reformation abolition of the division between the sacred and the secular and on the State's power to implement ethical solutions to public problems" (Quandt 1973: 402-3). The state was thus the key driving force in reducing inequalities.

Likewise, Cranfill specified the vision that Ely had of reducing inequalities, seen as "inequalities of opportunity." Imbued with his militant actions, "Ely believes in social progress toward a condition under which each member of society secured equal opportunity to develop to the full extent of his capacity. [...] The State with all of its institutions coordinated and cooperating should be ready to step in on the side of the weak and to check the strong when the latter showed any tendencies to exploit or harass the weak" (Cranfill 1941: VII).

Henceforth, the meaning of the reform of institutions was clearly established. While the change in property law was to be designed with a view to reducing the effects of "unequal opportunities," it was not simply a case of empty words, or naivety in the "Golden Mean" program. This program corresponded to a state of mind: the reform had to be undertaken by an elite, trained to manage social change (Herzberg 2001: 137). In Ely's mind, this elite was the group of intellectuals and politicians who identified with the Wisconsin Idea (Cavalieri 2016).

This elite had its means of action and the methods necessary to implement this change. In defining the means, Ely adopted a rather singular approach for the time. In Property and Contracts in Their Relations to the Distribution of Wealth, he meticulously established that it was essentially the decisions of judges, those stringent defenders of the Constitution, that prevented the fair distribution of wealth from occurring. The numerous appendices to the chapters listed a plethora of scenarios in which the judge's decision was over-protective of property rights, presenting the latter as an intangible right and, more often than not, rejecting the salaried worker's requests for reparations or better pay. Ely felt that action on means needed to be twofold: first, creating commissions bringing together intellectuals, employers and representatives of the civil society tasked with studying possible reforms - Ely would be the initiator and a member of the first commissions; and second, increasing the awareness of judges who would be trained in a "social theory of property" (Ely's own expression throughout his works) developed on the basis of ethical considerations to guide institutional change (Morehouse 1969: 15). On this, Ely was directly influenced by Knies (Heidelberg) and Wagner (Berlin).

With regard to methods, the "Golden Mean" program was clearly not a public policy mechanism that was sufficiently detailed to be immediately operational (Frey 2008: 310). As a reformist intellectual, Ely put forward new principles capable of providing a reasoned framework for institutional change. In addition to a general call for greater democracy, Ely discussed an "incentive mechanism," 
which can be pieced together by reading his autobiography published in 1938 (Ely 1938). This mechanism, conducive to "social change" - which scholars of his life and works believe remained the aim underpinning Ely's approach comprised three complementary ideas.

First, Ely spent several decades developing his global influence on how economic policy should be implemented. He maintained ongoing relations with numerous politicians of the Progressive Era (in particular, Robert - "Bob Fighting" - La Folette), as well as with President Wilson, who freely acknowledged the influence of his former professor on his actions (Wilson 1913). This influence was not solely intellectual, as Wilson's first term in office saw the adoption of a proportional income tax, the Federal Reserve Act and "new regulations on the economy" (Pequet and Thies 2010: 74), as called for by Ely and his students.

Second, building on this general influence on policy matters, Ely and his friends (in particular Commons) participated widely in the work of a wide range of policy reform commissions, most particularly that of the commissions of the "experimental" state of Wisconsin, now recognized as the laboratory of the New Deal (Gonce 1996). At the same time, Ely initiated a number of professional associations boasting a major reformist impact. In particular, Da Costa (2010) points to the decisive role of the American Association for Labor Legislation (created by Ely) in the fight to adopt social legislation in the United States.

Ely believed deeply in the supervision of private enterprise by the institutions, which defined the limits of freedom vis-à-vis the collective interest (Groves 1969: 8). More precisely, Ely developed an original means of acting on economic policy: "The men and women of the progressive movement should be seen as pioneers of the welfare state. Their aim was not to strengthen government authority as such, but they were determined to remedy the most urgent and dangerous ills of industrial society and in doing so, they quickly learned that they could not achieve their goals without using the power of the administrative state" (Hofstadter 1963: 15).

Finally, Ely gambled on comprehensive change in the means of teaching the elite in universities, prioritizing a more analytical mindset and innovative scientific approaches (in particular, the analysis of facts by "sifting and winnowing"). These ambitions were put into practice by means of teaching in interactive seminars, the involvement of professionals and company visits - an avalanche of new practices in the world of American academia in the early twentieth century. In this respect, Ely had a major impact on the social sciences in the USA, as he taught the most economists during this period (Tilman 1987: 142), while developing both the most prominent research and advisory institutions and the most original methods. In particular, he was the first person to create a department of agricultural economics in the United States, in 1909. 


\section{CONCLUSION}

Ely gradually disappeared from American social sciences after the early twentieth century, though he had an acknowledged scientific excellence and connections to the recognized between-the-wars institutional stream (Rutherford 2012). The history of thought nevertheless acknowledges his role as a pioneer in the ascension of Old Institutionalism, be it through the theoretical insights contained in his major works or through the training of the main professors forming this movement over several decades (Fine 1951). While this pioneering role is recognized even by his most virulent critics (in particular, S. Newcomb), neoclassical thought nevertheless made every effort to limit his place in the history of thought, granting him only a few mundane lines in the New Palgrave.

During his lifetime, Ely frequently faced quite strenuous opposition: a famous "trial" (Rolnick 1955; Schlabach 1963), as well as public attacks on his methods and the quality of the work conducted by the institutions that he founded. One of the most virulent attacks was that of Jorgensen in 1925, relating to the Institute for Research in Land Economics and Public Utilities (Jorgensen 1925). Despite this, the influence of the work of the research "institutions" that he created is now commonly acknowledged (Rocca and Vallet 2019).

Assisted by Commons, Ely remains the pioneering author of major institutional developments that marked the twentieth century in the United States. The provisions of the second New Deal with regard to social legislation and public intervention, for example, are the direct result of Wilson's experience and the work of commissions influenced by Ely's philosophy (Higgs 1987).

In his final work in 1938, Ely nevertheless felt that the reformist provisions of the second New Deal were ultimately of an overly socializing nature. This is evidence of a man torn between the firm conviction of a desire to reform capitalism and the profound influence of a conservative education.

\section{NOTES}

1. Outlines of Economics (1893), initially published in 1889 under the title An Introduction to Political Economy, was the most influential economics textbook in late nineteenth-century United States. The Times (October 7, 1937) stated that "probably not since the publication of Adam Smith's Wealth of Nations has a book of its kind had wider circulation." Ely founded the American Economic Association (AEA). His book The Labor Movement in America (1886a) - for many years the reference manual for United States labor economists - founded United States institutional labor economics (Kaufmann 2003). To labor relations specialists, Ely's work echoed the 1897 work of the Webbs. 
2. Four of Ely's works are generally recognized as being truly significant, with respect to their originality, their political scope or the analytical and theoretical synthesis provided: (1) "The Past and the Present of the Political Economy" (1884) provides a synthesis of the criticisms of classical political economics; (2) The Labor Movement in America (1886a) is the founding act of the tradition of institutional labor economics in the United States (Kaufmann 2003; McNulty 1980: ch. 6); (3) Outlines of Economics (1893), updated several times with co-authors, is a seminal book that remains the most influential economics textbook in late nineteenth-century United States, as mentioned in footnote 1. This textbook was immediately translated into several languages, and more than 500,000 copies were sold in the USA; (4) Property and Contracts in Their Relations to the Distribution of Wealth (1914) forms the very heart of his theoretical proposal, justifying the reform of property rights with a view to establishing a more equitable economy. The specific contributions of each of these four works to the "Golden Mean" project are explained in greater detail in the following pages.

3. In more than one hundred academic publications and extensive correspondence, Ely's most telling publications were written between 1884 and 1914. His autobiography (Ground Under Our Feet) naturally appeared much later (1938). Archived in the Library of the State Historical Society of Wisconsin, Ely's correspondence (the "Ely papers") has been examined and analyzed on several occasions. Two such analyses are reference works. The first is that of H. C. Taylor (1966), devoted to one of Ely's co-authors (E. W. Morehouse). The second work, by B. G. Rader (1966), is more familiar. Furthermore, E. W. Morehouse (1969) provides a periodized and thematic review of Ely's works.

4. In the introduction to his work, Bradizza (2013: 7) offers an extensive review of the opinions concerning the influence of Ely's publications. Bradizza provides a list of authors who consider that Ely's works over the period 1880-90 were highly influential.

5. The development of the GHS comprised two "schools" of thought, the first forming around Hildebrand, Roscher and Knies, and the second around authors such as Gustav von Schmoller or Adolph Wagner, for instance.

6. See, for instance, the following quotation: "At bottom, it [supply-and-demand analysis] is only a truism proved by the experience of cooks. When fish is scarce it is dear. In sooth, a beautiful discovery! Nevertheless, there is nothing necessary in this. Suppose a religious law which forbids one to eat fish; it might be very scarce and at the same time cheap" (Ely 1884: 39).

7. In 1917 Ely wrote, "In our work in this state, we have three watch words, namely patriotic, sanely progressive, and anti-Bolshevik" (quoted by Tilman 1992: 102). In 1938 Ely (1938: 224) once again explained his aversion for socialism, something quite clearly confirmed by the literature (Wilkins 1958).

8. This project was not dissimilar to the work of Henry George, and in particular his denunciation of a market economy characterized by owners acquiring wealth (see this volume, Chapter 14).

9. In reference to the title of the article written by M. N. Rothbard (2002). 


\section{REFERENCES}

Bradizza, Luigi. 2013. Richard T. Ely's Critique of Capitalism. New York: Palgrave Macmillan.

Cavalieri, Marco. 2016. "Inside Institutions of Progressive-Era Social Sciences: The Interdisciplinarity of Economics and Sociology." Journal of Economic Issues 50, no. 2: 345-61.

Coats, Alfred W. 1993. The Sociology and Professionalization of Economics. London and New York: Routledge.

Cranfill, Samuel Elliott. 1941. "The Contributions of Richard T. Ely to Economic Thought." LSU Historical Dissertations and Theses 7843. Available at https:// digitalcommons.lsu.edu/gradschool_disstheses/7843.

Da Costa, Isabelle. 2010. "John Commons' Institutionalism and the Origins of the Welfare State in the United States." Papers in Political Economy 42 [journal available online].

Dorfman, Joseph. 1949. The Economic Mind in American Civilization. New York: Viking Press.

Ely, Richard T. 1884. "The Past and the Present of Political Economy." Studies in Historical and Political Science of Johns Hopkins University Second Series: 5-64.

Ely, Richard T. 1885. "Pullman: A Social Study." Harper's Magazine 70 (February): 452-66.

Ely, Richard T. 1886a. The Labor Movement in America. New York: T. Y. Crowell.

Ely, Richard T. 1886b. "Ethics and Economics." Science 7, no. 175: 529-33.

Ely, Richard T. 1889. An Introduction to Political Economy. New York: Chautauqua Press.

Ely, Richard T. 1891. "Pauperism in the United States." History of Economic Thought Articles 152, no. 413: 395-410.

Ely, Richard T. 1894. Socialism and Social Reform. New York: Thomas Y. Crowell \& Co.

Ely, Richard T. 1900. "Letter to Woodrow Wilson." The Papers of Woodrow Wilson, April 20. Geneva: Archives of the League of Nations, 11 (1898-1900): 535.

Ely, Richard T. 1914. Property and Contracts in Their Relations to the Distribution of Wealth. New York: Macmillan.

Ely, Richard T. 1918. "Private Colonization of the Land." American Economic Review 8, no. 3: 522-48.

Ely, Richard T. 1938. Ground Under Our Feet: An Autobiography. New York: Macmillan.

Fine, Sydney. 1951. "Richard T. Ely, Forerunner of Progressivism, 1880-1901." The Mississippi Valley Historical Review 37, no. 4: 599-624.

Frey, Donald E. 2008. “The Impact of Liberal Religion on Richard Ely's Economic Methodology." History of Political Economy 40, no. 5: 299-314.

Gonce, Richard A. 1996. "The Social Gospel, Ely, and Commons' Initial Stage of Thought." Journal of Economic Issues 30, no. 3: 641-65.

Gough, Robert J. 1991. "Richard T. Ely and the Development of the Wisconsin Cutover." Wisconsin Magazine of History 75, no. 1: 2-38.

Groves, Harold M. 1969. “R. T. Ely: An Appreciation.” Land Economics 45, no. 1: 1-9. Herzberg, David L. 2001. "Thinking through War: The Social Thought of Richard T. Ely, John R. Commons, and Edward A. Ross during the First World War." Journal of the History of the Behavioral Science 37, no. 2: 123-41. 
Higgs, Robert J. 1987. Crisis and Leviathan: Critical Episodes in the Growth of American Government. New York: Oxford University Press.

Hofstadter, Richard (ed.). 1963. The Progressive Movement, 1900-1915. Englewood Cliffs, NJ: Prentice-Hall, Inc.

Jorgensen, Emil O. 1925. False Education in Our Colleges and Universities: An Exposé of Prof. Richard T. Ely and His "Institute for Research in Land Economics and Public Utilities." Chicago, IL: Manufacturers and Merchants Federal Tax League.

Kaufman, Bruce E. 2003. "John R. Commons and the Wisconsin School on Industrial Relations Strategy and Policy." Industrial and Labor Relations Review 57, no. 1: $3-30$.

Kloppenberg, James T. 1986. Uncertain Victory: Social Democracy and Progressivism in European and American Thought, 1870-1920. New York: Oxford University Press.

Kummerow, Max. 2004. "Richard T. Ely's Property and Contract in Their Relation to the Distribution of Wealth (1914): Did the Historical School Institutional Economists Invent a Workable Solution to 'Recurrent Crises of Capitalism'?." Working paper, available at http://citeseerx.ist.psu.edu/viewdoc/download?doi=10 .1.1.201.5389\&rep $=$ rep1\&type $=$ pdf.

McNulty, Paul J. 1980. The Origins and Development of Labour Economics: A Chapter of the History of Social Thought. Cambridge, MA: MIT Press.

Morehouse, Edward W. 1969. "Richard T. Ely: A Supplement." Land Economics 45, no. 1: 10-18.

Obeng-Odoom, Franklin. 2015. "Luigi Bradizza: Richard T. Ely's Critique of Capitalism." Journal of Economic Issues 49, no. 3: 887-90.

Pecquet, Gary M. and Clifford T. Thies. 2010. "The Shaping of a Future President's Economic Thought. Richard T. Ely and Woodrow Wilson at 'The Hopkins'." The Independent Review 15, no. 2: 257-77.

Quandt, Jean B. 1973. "Religion and Social Thought: The Secularization of Postmillennialism." American Quarterly 25, no. 4: 390-409.

Rader, Benjamin G. 1966. "Richard T. Ely: Lay Spokesman for the Social Gospel." Journal of American History 53, no. 1: 61-74.

Rocca, Michel and Guillaume Vallet. 2019. "A Noble, but Failed, Attempt by R. T. Ely, A. W. Small and The German Historical School to Influence U.S. Social Science (1890s-1930s)." Seminar of the New School for Social Research. March 5, New York.

Rolnick, Stanley R. 1955. "Exceptional Decision: The Trial of Professor Richard T. Ely by the Board of Regents of the University of Wisconsin, 1894." Journal of the Arkansas Academy of Science 8, no. 22: 198-203.

Rothbard, Murray N. 2002. "Richard T. Ely: Paladin of the Welfare-Warfare State." The Independent Review 6, no. 4: 585-9.

Rutherford, Malcolm. 2001. "Institutionalism Then and Now." Journal of Economic Perspectives 15, no. 3: 173-94.

Rutherford, Malcolm. 2009. "Towards a History of American Institutional Economics." Journal of Economic Issues 43, no. 2: 308-18.

Rutherford, Malcolm. 2012. "Field, Undercover, and Participant Observers in US Labor Economics: 1900-1930." History of Political Economy 44, no. 5: 185-205.

Schlabach, Theron, F. 1963. "An Aristocrat on Trial: The Case of Richard T. Ely." Wisconsin Magazine of History 47, no. 2: 140-59.

Stiglitz, Joseph. 2012. Le Prix de l'Inégalité. Paris: Les Liens qui Libèrent. 
Swayze, Francis J. 1915. "Review on Property and Contract in their Relation to the Distribution of Wealth by Richard T. Ely." The Quarterly Journal of Economics 29, no. 4: 820-28.

Taylor, Henry C. 1966. "E. W. Morehouse: The Academic Years and the Heritage of Richard Ely." In Innovation and Achievement in the Public Interest Essays on Government, Business and the University in Honor of the Seventieth Birthday of Edward W. Morehouse, edited by Ward Morehouse and Nancy Morehouse Gordon. Croton-on-Hudson, NY: Wayward Press, pp. 1-17.

Tilman, Rick. 1987. "Grace Jaffe and Richard Ely on Thorstein Veblen: An Unknown Chapter in American Economic Thought." History of Political Economy 19, no. 1: 141-61.

Tilman, Rick. 1992. Thorstein Veblen and His Critics, 1891-1963. Princeton, NJ: Princeton Legacy Library.

Wilkins, Myra S. 1958. "Richard T. Ely on English Socialism." The American Journal of Economics and Sociology 18, no. 1: 61-8.

Wilson, Woodrow. 1913. The New Freedom. New York: Doubleday, Page \& Company. 